\title{
Crime and Punishment in pre-Hispanic Nahua City-States Tenochtitlan and Texcoco
}

\section{PETER VYŠNÝ}

Department of Legal History

Trnava University, Trnava, Slovakia

petervysny@hotmail.com

\begin{abstract}
The article focuses on the delinquency existing in pre-Hispanic Tenochtitlan and Texcoco as a particular type of human behavior, having many concrete forms that the wider society perceived (and condemned) through certain concepts and that it sought to both prevent and suppress. The first part of the article deals with the reflections and forms of delinquency existing in Tenochtitlan and Texcoco. In the second part of the article the mechanisms of prevention and repression of delinquency are examined. Although the preHispanic society existing in Tenochtitlan and Texcoco can be considered as a so-called shame culture, in the conclusion of the article it is suggested that it could be a shame culture, which over time has changed, to a certain extent, to a so-called guilt culture.
\end{abstract}

KEY WORDS: pre-Hispanic period, Nahuas, Tenochtitlan, Texcoco, delinquency, shame culture, guilt culture

\section{Introduction}

The neighboring Nahua city-states Tenochtitlan and Texcoco (Tetzcoco, Tezcoco) were located in the Mexican Valley in Central Mexico, one of the relatively separate cultural and historical areas of pre-Columbian Mesoamerica. Tenochtitlan and Texcoco, together with the neighboring city-state Tlacopan, were the three cooperating, political, military, 
economic and cultural centers of the Aztec Empire (the second quarter of the 15th century $1521 \mathrm{BC}$ ). During the second half of the 15th century, Tenochtitlan became the largest and most populous urbanized settlement ${ }^{1}$, as well as the main and politically, militarily, economically and ideologically the most powerful center of the Aztec Empire. ${ }^{2}$ Its inhabitants were called Tenochca or Mexica-Tenochca. The inhabitants of Texcoco, the second most important center of the Aztec Empire after Tenochtitlan, were called Acolhua. Finally, the inhabitants of Tlacopan were called Tepaneca. The inhabitants of these cities, sometimes referred to collectively as the Aztecs, spoke the same language, and belonged to the same, wider culture of the Nahuas, which dominated Central Mexico, but was not the only culture of this area.

The Nahua culture was multiethnic and consisted of about 20 ethnic groups (SMITH 2012:4). The Nahuas lived in many city-states or altepeme (sg. altepetl). There were dynamic complex relationships among the Nahua city-states that had different forms trade, alliance formation, including the "marriage of reason" between female and male members of the dynasties ruling in the city-states, intercourse for the purpose of the joint exercise of religious rites, and so on; Nahua city-states also often led wars with each other. The size, population, economy, position in international relations, etc. of the concrete citystates has varied, but at the same time they also had some typical common features that included, for example, the institution of the ruler of the city-state - tlatoani (literally "he who speaks"; pl. tlatoque), monumental architectural structures built for religious and administrative purposes (e.g. a pyramidal temple in which the deity considered a patron of the city-state was worshiped), or the market/the central square. ${ }^{3}$

Over the past decades, various aspects of the society existing in the pre-Hispanic Tenochtitlan and Texcoco have been examined, but researchers have not paid the same attention to individual aspects. One of the aspects, which is examined only to a lesser extent and briefly dealt with in this article, is delinquency existing in both cities.

In this article, I am based on an elementary sociological understanding of delinquency as a kind of human behavior which is inconsistent with legal (= binding) norms and that is antisocial, i.e. it is harmful to society, a particular part of society or specific members of

\footnotetext{
1 It was spread over an area of about 1,350 hectares and had about 212,500 inhabitants (SMITH 2005:411)

2 See e.g. SMITH 2008:2-4.

3 See e.g.: HODGE 1996:4-88; SMITH 2000:581-595.
}

DOI: 10.1515/eas-2017-0008 @ University of SS. Cyril and Methodius in Trnava. All rights reserved. 
society. Delinquency involves both deeds regarded as crimes by penal law and other unlawful/anti-social acts (JANDOUREK 2012:47-48). The delinquency existing in a society, of course, has many concrete forms with varying degrees of seriousness, and these forms are both prevented and repressed by the society/state to a varying extent.

In this article, delinquency is seen as an integral part of the complex everyday life of Tenochtitlan and Texcoco inhabitans. According to the theory of the history of everyday life (Alltagsgeschichte), people's daily and mostly routine actions are redefining various social relationships and structures every day, allowing them to survive for longer. On the other hand, people also frequently engage in actions which, depending on their current needs, interests, goals, attitudes, or life experiences, modify, develop, disrupt/revise, circumvent, or manipulate existing social relationships and structures in their favor, or attempt to break out of their influence or to act contrary to them (LÜDTKE 1995:5-7, 16). Of course, such actions also include delinquency.

In this article, I examine the delinquency existing in the pre-Hispanic Tenochtitlan and Texcoco as a type of human behavior, having many concrete forms that the wider society perceived to be negative, which it sought to prevent and which it also sought to suppress. The article is composed of two parts. In the first part of the paper I deal with the reflections and forms of delinquency existing in Tenochtitlan and Texcoco, in the second part with the mechanisms of its prevention and repression (i.e. social control mechanisms). Although the pre-Hispanic society existing in Tenochtitlan or Texcoco can be considered as a so-called shame culture, in the conclusion I briefly point out that it could be a shame culture, which has changed, to a certain extent, to a so-called guilt culture. I try to examine the issue of the article not only from an etic, but also from an emic perspective. Research from the later perspective is, however, only possible to a very limited extent, since: 1) emic interpretations of the first degree are, of course, inaccessible to the investigator, that is, the investigator can access only approximately and incompletely the authentic thinking of the investigated people, from the wider socio-cultural context surrounding them (GEERTZ 1973:15 ff.); and 2) the written sources on which the knowledge of the Nahua pre-Hispanic past is based originated after the Spanish conquest of the Aztec Empire (after 1521), and therefore only partially contained an authentic view of the Nahua on their pre-Hispanic past. ${ }^{4}$

$4 \quad$ See e.g.: BERDAN 2014:3 ff; NAVARRETE LINARES 1997:155-179.

DOI: 10.1515/eas-2017-0008 @ University of SS. Cyril and Methodius in Trnava. All rights reserved. 


\section{Delinquency in Tenochtitlan and Texcoco}

Delict is incompatible with the values and norms of a particular society which is causing harm and the delinquent is threatened with punishment. Based on how the world's cultures conceptualize the delict, its detrimental consequences, as well as the personality of the delinquent and his attitude towards the delict (and its detrimental effect), they can roughly be divided into the so-called guilt cultures and the so-called shame cultures. The concepts of guilt culture and shame culture were developed by R. Benedict in her famous work The Chrysanthemum and the Sword of $1947 .^{5}$ Both concepts are still in use, although their scientific reflection in recent decades has been critical. ${ }^{6}$

Guilt cultures and shame cultures cannot be universally defined, as guilt and shame are emotions that different cultures have differently viewed and that have differently influenced individual behavior and interpersonal relationships (YING WONG - TSAI 2007:209-224). Broadly speaking, while guilt is a certain inner psychic state and refers to the conscience of the delinquent, i.e. it is "visible" or "palpable" only to the perpetrator himself and not to other people, the shame the individual has thrown on him, on the contrary, is "seen" by other people, i.e. shame is manifest in some way externally (e.g. people despise people affected by shame). Additionally, guilt can be remedied, but not shame, or not completely. Shame can be completely "washed away" only by the death of a person who, through his devious behavior, has shame (ASSMANN 2012:154).

In a shame culture, collectivist mentality is prevalent, the delinquent's individuality is weakened, and a delinquent is seen as an integral part of a community (e.g. a tribe or a nation), whose members are associated with a certain solidarity, therefore a delinquent experiences the consequence of his delict, i.e. the shame he shares with other members of his community. He is thus affiliated with the members of his community with shame, but he is not individually responsible, i.e. personally guilty of committing a crime, at least not outwardly (outside the community). On the other hand, in the guilt culture, the individualistic mentality is predominantly applied, the delinquent's individuality is not fundamentally weakened and the consequence of the delict is an individual responsibility, i.e. the personal guilt of the offender. In principle, it can also be stated that while in a shame culture a delinquent violates the values and norms of a particular community, which is one of the relatively autonomous and self-governing components of a wider society, in a guilt

$5 \quad$ For more details see BENEDICT 1947.

$6 \quad$ See e.g. CREIGHTON 1990:279-307.

DOI: 10.1515/eas-2017-0008 @ University of SS. Cyril and Methodius in Trnava. All rights reserved. 
culture the delinquent violates the rules of conduct (mainly legal norms) which are the same for the whole society, which is not divided into autonomous communities (FIKENTSCHER 2009:425).

Patrick K. Johansson assigns the Nahuas to the shame cultures (JOHANSSON 2010:91136). The reason for this assignment, according to Johansson, is above all the Nahua general understanding of the delict. The Nahuas did not perceive the delict (tlahtlacolli) as a sin in the Western/Christian meaning, although it was precisely this meaning which was given to it by the authors of the written sources. In the Nahua case, the delict was not a contravention of moral norms - it was not understood as the opposite of the abstract good, or as evil itself, because the well-established dichotomy of good and bad did not exist. The delinquent was behaving contrary to social norms, which is an unwanted and "tangible" violation of the social order, by interfering with its normal functioning, which manifested itself as a certain observable unfavorable consequence - a damage or injury. The normal functioning of the social order could not be restored by the fact that a supernatural/divine being forgave the delinquent of his sin but only by a mechanical "reparation" of the social order "injured" by the delict. However, since for the Nahuas social order was part of the supernatural world order created and governed by the gods, they attributed to the injury caused by the delict not only natural but also supernatural consequences. Thus, the restoration of the normal "running" of the world order often required a remedy consisting of the application of not only real sanctions (e.g. indemnification), but also supernatural punishments that took the form of rituals with a religious-symbolic content (the character of a religious ritual can comprise, for example, the death penalty (JOHANSSON 2010:95).

The Western/Christian understanding of the delict as a deed of moral evil, which means that the person has free will and can freely choose to commit evil, but then he/she is personally responsible, i.e. guilty, did not exist among the Nahuas. It was related to the fact that delinquent behavior was basically considered to be the inalienable destiny (predestination) of a delinquent (JOHANSSON 2010:97). On the other hand, the Nahuas admitted that a person can, to a certain extent, be able to reverse his unfavorable predisposition, in our case the predestination to be a delinquent, by his own efforts (by constant self-control, by overcoming the temptation to commit evil, by ethically correct decision-making and acting, etc.) (VYŠNÝ 2012a:127-130).

Thus, in the philosophical plane, the imaginative association of the Nahua delinquent with the delict he committed did not rest on the notion of his personal guilt. This connection was expressed by another concept, namely shame (pinahuiliztli). Shame had to be avoided not only for man's natural fear of shame, but also for a more specific reason - the belief that if 
a man suffers shame, his physical and mental abilities will be reduced (JOHANSSON 2010:97-98).

It may also be noted that the Nahua view of the delict corresponded to the concept of a public crime (crimen publicum), i.e. the delict was public in nature, even if it threatened or attacked the private interest of a particular individual. Therefore the prevention and repression of delinquency was realized on behalf of the whole society and by its power institutions, i.e. by the state apparatus, and not by private persons because private revenge was forbidden (KATZ 1989:186). Besides, there were certain offenses for which the state power did not punish the offender; these were the offenses of children who (especially physically) punished their parents, and the offenses of students in public schools who (in particular, physically) punished their teachers (LÓPEZ AUSTIN 1961:117-123; LUZ LIMA 1986:13-15).

Understanding the delict as a crime was also a manifestation of the considerable development of criminal law in Tenochtitlan and Texcoco. There were similarities and differences between the legal orders of Tenochtitlan and Texcoco. However, in the sphere of criminal law, similarity seems to have prevailed (VYŠNÝ 2015:76), which in principle makes it possible to see the criminal laws of both city-states as a single criminal law. In written sources, among the legal norms, registered criminal law norms significantly outweigh the others. From these sources, it is also clear that criminal law was characterized by a high level of complexity - its proper (by state-power) sanctioned norms regulated a number of crimes against the state, (strict) discipline of soldiers, officials, judges and priests, public morals, life and health of the people, family, property, and so on (VYŠNÝ 2012a:179 ff.). On the other hand, the information value of these sources as sources of knowledge of the criminal law of Tenochtitlan and Texcoco is limited.

There was a rich Nahua literature in the pre-Hispanic period, partly captured in the Nahua pictographic and ideographic writing and partly in oral traditions. This literature had various, e.g. historical, religious and legal content (HILL BOONE 2000). The written sources originating from the period after the Spanish conquest, i.e. from the early colonial period (the 16th century after 1521 and the 17th century) are based, to some extent, on the pre-Hispanic Nahua literature but they reproduce it with many modifications and deformations (VYŠNÝ 2012a:15 ff.). These objectively resulted from the fact that the written sources originated in a new colonial environment characterized by insufficiently complete and/or correct understanding of Indian cultures by the colonizers (Spaniards) as authors of some sources, and vice versa. However, they were frequently intentionally done when both Spaniards and Indians manipulated or even invented information about the pre- 
Hispanic past, so that they could support their own power and property interests. ${ }^{7}$ In sources created by the descendants of women belonging to the Nahua elite and the Spaniards, we find idealizations and other "politically correct" adjustments of this past, which aimed to present it in a way that would allow the Spaniards to accept it in terms of their value and normative standards, which had to stylize Nahuas in the position of people morally and culturally equivalent to the Spaniards, thus legitimizing the efforts of the offspring of pre-Hispanic elites to strengthen their position and gain certain advantages in early colonial society. In these sources, for example, one can read that the criminal law rigorously - by death - punished male and female homosexuality, premarital sexual intercourse, adultery, or violation of priestly celibacy, which probably did not fully correspond to pre-Hispanic realities, but it corresponded very well to contemporaneous Spanish/Christian values (JOHANSSON KERAUDREN 2009:33-72).

In Tenochtitlan and Texcoco, they seem to classify crimes in terms of their severity into "serious" and others. Serious crimes (tetzauhtlahtlacolli) included various attacks against the state, i.e. the tlatoani, elite and social order, as well as military crimes, murder, robbery, theft, adultery and, last but not least, public drunkenness (VYŠNÝ 2012a:177).

Serious and other crimes can be divided into the following categories:

a. Crimes against the state/tlatoani. For example, treason. The traitors were quartered. However, treason was such a serious crime for the Nahuas that the traitor's death was not a sufficient punishment for them. Thus, the traitor's descendants and other relatives were also punished (they were enslaved for four generations). Moreover, the house of the traitor had to be buried, which was accomplished physically by its devastation and demolition and symbolically, by digging at the place where the house stood until the underground water had cleared - a symbolic "effacement" of a traitorous family from the community of the citystate; the land on which the traitor's house stood, was sprinkled with salt, which was to prevent the people from settling down on the land in the future.

b. Crimes committed by civil servants. For example, corruption. A judge who took a small bribe was forever freed from his office and also shrouded, which was

For example, the liberation of the Nahua elites from the tax payment before the conquest, mentioned in some sources, is most likely the invention of these elites, which should justify their attempts to be exempted from taxation in early colonial society (LOCKHART 1992:106-107). 
considered a shameful punishment. But if a judge took a bigger bribe, he was executed.

c. Military crimes. There were various violations of discipline which were expected from warriors; these violations were punished by death.

d. Crimes against Nahuas' values and morals. This category of criminal offenses included, inter alia, sexual offenses such as incest, homosexuality (both male and female), rape, adultery or prostitution. The perpetrators of these offenses were punished by death. An exception was prostitution that was carried out by women who did not belong to the elite.

e. Crimes against the family. For example, a son who seriously verbally or physically attacked his parents or did not obey them or caused shame to the parents by his behavior, could be executed (and at the same time he could be disinherited so his offspring could not inherit from his parents).

f. Crimes against freedom and human security. The main offense was the seizure of a free person, particularly a free child, and his/her surrender to slavery. The perpetrator of this crime was punished by enslavement.

g. Crimes against human life and health. They included, for example, murder (the murderers were mostly executed), or abortion (a woman who had herself aborted or asked someone or allowed someone to commit an abortion was executed).

h. Crimes against property. For example, theft. Depending on the seriousness of the theft committed, thieves had to pay a fine equal to twice the value of the stolen case (a certain amount of the fine was paid to the robbed person for compensation and a certain part to the state), or they were enslaved in favor of the robbed person. Even if in a profane context thieves were uncompromisingly prosecuted and punished, in a ritual context the theft was tolerated in certain cases, i.e. it was part of some religious rituals. For example, part of the celebration of the panquetzaliztli religious ceremony was the struggle between students (sons) attending the school for ordinary people (telpochcalli) and those from the school for elite sons (calmecac). When the match was won by the students of the calmecac, they could persecute the telpochcalli students to the palace of tlatoani, imprison them there and remove some things from the palace (e.g. mats, seats, drums). However, if the telpochcalli students won, the calmecac school students could be imprisoned in their school building and the winners could take away from it anything they wanted (VYŠNÝ 2012a:179 ff.). 
Nahuas had not only the concept of the delict, but also the concept of the delinquent. They considered him/her to be a human without a face, i.e. an incomplete and at the same time a despicable person, who can hardly "improve", who should be shunned by other people, and who cannot avoid the punishment he/she deserves (LEÓN-PORTILLA - SILVA GALEANA 1991:55-59, 83-86). The term "face" (ixtli) was understood as one of two essential constituent elements of the human as a person. He/she marked the constant character of a human who, according to Nahua, had a sense of reason. The second element was the so-called "heart" (yollotl), which should be firm. This concept reflected the day-today decision-making and actions of a person as governed by certain rules adopted through family and school education (LEÓN-PORTILLA 1993:189-202).

Nahuas had a particular figurative term for a person suspected of committing a crime - they called his/her face ash-stained. It was a person who was generally aware that he/she had committed a crime, even though he/she was still convinced that he/she would conceal committing a crime (SAHAGÚN 2001a:588). Symbolism of the dirty face is obvious - dirt is a metaphorical expression of crime. The fact that the public seriously suspected some people of committing a crime and was convinced that they could not escape punishment is related to the possibility of initiating a criminal trial on the basis of mere "speech" or "gossip" that was publicly disclosed (VYŠNÝ 2012a:122).

According to the criminal law of Tenochtitlan and Texcoco, the delinquent could be a male and female of any social status who at the time of committing the crime reached the age of at least 10 years (TORQUEMADA 1969:564). With the exception of treason, in case of which not only the traitor, but also his family members were punished (VYŠNÝ 2012:181182 ), only the perpetrators themselves were punished. It remains to be added that the coperpetrators and persons who participated in some way in committing a crime (e.g. gave the offender some help facilitating the commission of a crime) were also punished (VYŠNÝ 2012:174).

\section{Mechanisms of prevention and repression of delinquency in Tenochtitlan and Texcoco}

The first mechanism we shall mention is the systematic education of Nahua children by their parents which should prepare them well for the life in society (they should learn how to work properly, to obey public authorities and so on), as well as for marriage and parenthood. Parents had the right to admonish their children and from the age of 9 they 
could punish them rather physically, but they had no right to kill their children. Parents could also sell a son with problematic behavior into slavery, which was subject to court authorization (VYŠNÝ 2012:156 ff.).

Another and seemingly effective means of disciplining the population was to educate children of both sexes, to a greater extent and longer, but only of boys, in state schools, coupled with intense formation of pupils' thinking and behavior. Children entered these schools between the ages of 12 and 15 and remained there until they reached the age of marriage (in the case of women, 15 to 18 years of age, in the case of men 20 to 22 years of age). ${ }^{8}$

Another form of social control was to persuade the population of the necessity and correctness of the social order through material culture. The Nahua social order was considered to be a part of the supernatural world order established by the gods which was the opposite of chaos and therefore something positive. Some material remains of the past, for example, the great pyramids, the alleged giants' works, or the bones of prehistoric megafauna, were interpreted by the Nahuas as physical evidence of the existence of the age that preceded the age of the Nahuas (the Nahua age was called nahui ollin, the Fifth Sun), and at the same time as evidence that it was an age in which real (fully developed, normal) people did not live, but, for example, "giants" lived. When Nahua put this age in contrast with their own, i.e. human age, it turned out that while the previous age was something negative, because real people did not live in it, the present age is something positive, as real people live in it. The social order prevailing in the current age was considered positive $a$ priori and so this order was the only possible and correct one (HAMANN 2002:355-357).

An important part of this form of social control was the so-called architectural communication, i.e. the materialization of certain essential ideas, on which, according to Nahua, was based the supernatural order of the world (and therefore the social order), in certain architectural objects and structures. For example, Tenochtitlan was built, inter alia, as a copy of Tollan, the mythical city of the Toltecs, whose empire (10th-12th centuries BC) enjoyed considerable respect in Central Mexico, and therefore in Tenochtitlan its inhabitants placed publicly available items of Toltec origin, as well as imitated Toltec architectural and artistic styles, and so on (LÓPEZ LUJÁN - LÓPEZ AUSTIN 2007:3483). Tenochca thus actually joined the toltecayotl, the prestigious ideological, cultural and political heritage of the Toltec Empire, which gave them the status of "civilized" people

8 For more detail see LÓPEZ AUSTIN 1985a; LÓPEZ AUSTIN 1985b.

DOI: 10.1515/eas-2017-0008 @ University of SS. Cyril and Methodius in Trnava. All rights reserved. 
and legitimized the existence of their state (Tenochtitlan as the new Tollan) and its imperial expansion (the expansion of Tenochtilan as the restoration of the Toltec Empire). Besides, Tenochca also attempted to manifest Tenochtitlan's link to the significant city of Teotihuacan (1st-7th century AD) and imitated certain architectural forms and decorative styles of architectural objects existing in Teotihuacan as they constructed the monumental buildings in the sacred district in the center of Tenochtitlan and placed certain artifacts originating from Teotihuacan into this district (LÓPEZ LUJÁN 1989). The physical representation of Teotihuacan in the public space of Tenochtitlan should have constantly reminded the Tenochca that Teotihuacan was the place where the world was created, as well as humans, and that this was accomplished, according to the mythology widespread in Mesoamerica, by self-sacrifice of the gods. Thus, certain elements of material culture should remind the inhabitants of Tenochtitlan that for their existence and for the existence of their world, they should give thanks to the gods and their sacrifice non plus ultra. The gods' self-sacrifice in some sense benefited the people, thus creating a debt to the gods, that must be repaid by the people, in particular by "the feeding of the gods" with human sacrifices. The elements of the material culture of Teotihuacan present in Tenochtitlan, whether original or imitation, communicated to those who viewed them daily not only the obligation to pay supernatural debt to the gods, but they also legitimized the social order of the Tenochtitlan as it was possible to claim that it was created and is maintained so that people can effectively repay their debt. Particularly, the political power and privileged social status of the rulers (tlatoque) and the elite (pipiltin) of Tenochtitlan were strengthened, as they led ordinary people (macehualtin) to fulfill the Tenochcas' mission to satisfy with human sacrifices the divine creditors of mankind (HAMANN 2002:355-357).

Other monumental architectural objects were the impressive "coulisses" of public spaces where, as in the theater stage, periodically conspicuous religious rituals were performed. These rituals communicated, at regular intervals, the essential ideas on which the complex world view of the Tenochca and other Nahua rested. There was, for example, the belief that the gods needed a regular supply of "nutrition", especially the supernatural forces released from the bodies of sacrificed people, so that they could maintain the existence and the right course of the world order through their supernatural activities. The rituals also gave prestige and authority to their performers - tlatoani and various elites. On the other hand, the audience (mostly macehualtin) of the rituals felt involved in something extremely important which strengthened their inner identification with the city-state, its ideology and social 
order, and thus their loyalty to the city-state. ${ }^{9}$ Rituals also increased the mutual cohesion of performers and spectators who together formed a single communitas (TURNER 1991:94 ff), i.e. a community of ritual participants within which social inequalities were wiped away and whose members were all united by the awareness of participation in the creation of the supernatural bonum commune resulting from rituals. In addition, the rituals shaped the behavior of their participants as they gave them certain roles associated with certain rules of conduct (MILLER 2005:1181-1233). For example, by a series of certain rituals, a person selected by the elite became the new tlatoani of Tenochtitlan, together with the obligation to perform the office in favor of his subjects; on the contrary, the common people and the elites of Tenochtitlan, by means of these rituals, took the position of the subjects of tlatoani, obliged to obey him and fulfill his orders (SAHAGÚN 2001:676 ff).

Even if all the aforementioned mechanisms of social control had great importance, I believe that the most efficient mechanism was (in Tenochtitlan as well as in Texcoco) systematic prosecution and punishment of offenders organized by the state, i.e. criminal trials, which had a complex institutional (state apparatus and courts as a special part of it), as well as legal (criminal law) basis (VYŠNÝ 2012a:78 ff.).

Criminal law norms have been applied largely universally, to macehualtin and pipiltin, but also to the relatives of the ruler (tlazopipiltin) (KOHLER 2002:123) and to the ruler himself (tlatoani), who, despite his considerable factual power and the function of the legislator, was no princeps legibus solutus (VYŠNÝ 2012b:71-110). The tlatoque, the heads of citystates' governments (tlatocayotl), were chosen from members of their monarchic dynasties. They were regarded as representatives of the gods, ruling by the will of the gods and in the name of the gods, and so they were all equal, although it was more theoretical than real. There was a belief that the end of the dynasty of any altepetl would be dangerous to the immutable order of the world established by the gods, and as a result, a dynasty militarily defeated by another altepetl would continue to govern (at least formally) in its altepetl. The killing of a tlatoani would be a form of sacrilege (ALMAZÁN 1999:165).

Courts conducted criminal trials against persons whom the judges suspected of having committed a crime. However, if there was a suspicion of committing the crime of adultery, but the adulterer was not caught in flagrante delicto, the court began investigating the case

$9 \quad$ The fact that the ritual can be an effective tool for identifying the population with an ideology and a social order has been convincingly shown in relation to classical Mayan cities, but, in my opinion, are also valid in other Mesoamerican contexts (e.g. for Tenochtitlan) (INOMATA 2006:805-842). 
only on the proposal of the (allegedly) deceived husband (ALVA IXTLILXOCHITL 1997:385).

Concerning the Nahua conception of prosecution and punishment of offenders it may first be noted that Nahuas viewed criminal justice as a beast who mercilessly devours all offenders without distinction (SAHAGÚN 2001a:476), from which it can be concluded that they were convinced that the offenders cannot escape their punishment. Nahuas denoted punishment with multiple expressions, e.g. by tetlatezacuiltiliztli (or: tetlatzacuiliztli) ${ }^{10}$ (OFFNER 1983:247-250). Metaphorically, punishment was designed, for example, like tetl quahuitl = stone, wood, to evoke the instruments were utilized in physical or capital punishment (OFFNER 1983:250, table 6.9).

The punishment of delinquents and especially the imposition of the death penalty should be distinguished from e.g. fasting or self-sacrifice (blood-letting), as well as from the sacrifice of people as activities carried out in a ritual context. The distinction of death as a punishment and death as a sacrifice to the gods was also reflected in the linguistic plane: death as a punishment was called miquiztlatzontequiliztli, death as a victim to the gods as xochimiquiztli $^{11}$ (JOHANSSON 2010:91).

In Tenochtitlan and Texcoco various types of punishment were imposed, namely the death penalty, corporal punishment, imprisonment, enslavement, dismissal from office, exile, deportation, public dishonor, loss of elite status (the convict was excluded from the pipiltin social class), removal of the entire property of the convict by the state/tlatoani, or only partially (the convict had to provide part of his property for the purpose of paying a fine or compensation) (VYŠNÝ 2012a:175).

The death penalty deserves particular attention, not only because it was used for a person who committed many crimes, but also because of its transcendental meaning as a means of "repairing" the supernatural order of the world that had been "injured" by serious crimes. This "reparation" appears to have been carried out, in the Nahua understanding, for example, by transferring of tonalli, a supernatural life force residing in the bodies of human beings, from a person sentenced to death to another person or thing to which the tonalli could then be of some benefit. The transfer of tonalli should be, the Nahuas believed,

10 The expression means "to impede some evil" or "to punish the others" ("el acto de impedir algún mal, o de castigar a otros") (THOUVENOT 2014:343).

11 This expression means "flowery death". The flowery death was seen as a kind of honourable death by the Nahuas.

DOI: 10.1515/eas-2017-0008 @ University of SS. Cyril and Methodius in Trnava. All rights reserved. 
caused by the fear of the convict coming from near death. Evidence of this concept may be the execution of some delinquents for the purpose of revitalizing the (supernatural) life force of the tlatoani or closing the prisoner waiting for death into a wooden cage that was placed next to the granary, indicating that the released tonalli should supernaturally benefit corn stored in the granary (JOHANSSON 2010:99-100) as an important and sacred food of the Nahuas. Considering that, for example, the periodic revitalization of the life force of the tlatoani was a necessity, since the tlatoani was the guarantee of the preservation of the supernatural world order, the idea was that the necessity was at least to a certain extent of delinquency for the optimal "course" of the world order. Namely, the maintenance of this "course" required not only the tonalli of persons sacrificed by the priests, but also that of the offenders sentenced to death by the courts. This idea favors the above-mentioned presumption that committing crimes was more of a predilection of man, which gave him a certain role necessary for the good functioning of the supernatural world order as the (exclusive) manifestation of his free will.

The imposition and execution of the death penalty were subject to complex religious laws which determined who has the power to impose the death penalty and who has the power to carry it out, as well as setting the date, place, method and instrument of the execution, as well as the physical part of a person sentenced to death to which he was executed.

The jurisdiction had professional judges with a knowledge of the law who did not impose the death penalty - that was the competence of tlatoani - but they could recommend that he imposed such a penalty. The tlatoani had the power to impose the death penalty on the day on which, according to the ritual calendar (tonalpohualli), a sign ce itzcuintli (1 Dog) appeared (SAHAGÚN 2001a:348). The execution of the convict was not performed by judges, but by professional executioners (temictique) (JOHANSSON 2010:107).

The date, place, method, and instrument of execution, as well as the physical part of the death-sentenced person to which the execution was directed, were given by the social status of the convict and the nature of the offense committed. At the same time, however, they also related to the various supernatural meanings that the Nahuas attributed to the fact that the executions took place on certain days, in certain places, in certain ways or by certain instruments (JOHANSSON 2010:107-134).

The possible date of execution for committing an offense resulted from the ritual calendar. The executions took place in the Macuilcalli Temple (Macuilquiahuitl), in the palace court Tecpilcalli, in the marketplace (i.e. publicly) or in a private house of the person sentenced to death. Executions were done by stoning, strangling, obstruction, drowning, burning (alive), decapitation, pulling out of the skin, firing arrows, sticking sticks, or gradually 
lowering the dose of the meal. The tools used to carry out execution included stones, ropes, water, fire, sticks, arrows, axes, or meals. As for the body parts of the convict facing the execution, it could be head, neck, breath, body as a whole, or skin (JOHANSSON 2010:107-134).

The circumstances under which a crime was committed were thoroughly examined by the court. The court also examined the possible presence of some aggravating or attenuating circumstances.

An aggravating circumstance was the commission of a crime by a person belonging to pipiltin and/or holding a civil or military office at the time of committing the crime, committing a crime at specific places - in the marketplace, in the palace of tlatoani, in the temple or on the battlefield, or committing a crime at a time when a war was taking place. Attenuating circumstances were when the relatives of the murdered forgave the murderer or when the deceived husband forgave his wife committing adultery (ALBA 1949:10).

If the offender committed two or more crimes, each of them was punished with appropriate penalty. Consequently, the punishment was based on the principle quot delicta tot poenae. The recidivists were given tighter sentences and the punishment could be tightened up to the death penalty (ALBA 1949:10).

Although the usual consequence of a commission of an offense was the imposition of a punishment, in certain circumstances it was possible to waive the punishment of the perpetrator. Criminal law made it possible not to punish the perpetrator of an offense if, after committing it, he had committed a valiant act on the battlefield, or by granting a grace or declaration of amnesty to the state (KOHLER 2002:126). Once in four years, during a feast in honor of god Tezcatlipoca, the state gave a general pardon to minor criminals (DURÁN 2002:48)

It is often reported in the literature that sexual delinquents (especially adulterers) were able to avoid their punishment through a "confession" done in front of a priest in the temple of the goddess Tlazolteotl. This "confession" was called neyolmelahualiztli $=$ the art of true presentation of the heart, and each person had the right to do it only once in a lifetime, so the Nahuas allegedly performed it only at a higher age or at the end of their life. On the other hand, priests could make a decision to sacrifice a person after the "confession". Thus, delinquent did not necessarily escape death by the confession that threatened them for commitment of a sexual crime on the part of secular justice (KOVÁČ 2002:264).

However, Johansson rejects the existence of the confessions in the Western/Christian sense among the Nahuas and offers another interpretation: the role of Tlazolteotl was not to 
forgive the person his/her sin after having it sincerely declared and reprimanded, but supernaturally to absorb the delict and at the same time to correct its detrimental consequences (as for the Nahuas the delict was similar to impurity and excrement, this activity of Tlazolteotl cum grano salis may be termed as a "ritual coprophagy"). For example, adultery, as it consisted of a sexual act, was, according to Nahuas, unnecessary consumption of fertility (it was a wasting of fertile force), causing a certain imbalance to the supernatural order of the world. Therefore the adulterers had to be punished and that would restore the balance of the world order. This was achieved particularly by stoning adulterers, which, from the Nahua point of view, could stimulate the emergence of a new fertile force that would complement the fertile force wasted away by adulterers. The stones that fell on the executed resembled rain and rain was one of the material manifestations of the fertile force. Throwing of the stones was a means of calling rain, i.e. of generating the fertile force (JOHANSSON 2010:95,97,100,112-113). In other words, the death penalty by stoning was actually a ritual belonging to the sphere of homeopathic magic. At the same time, we can see a typical feature of legal thinking here which can be designated as "archaic" 12 and which was present (in various periods) in many world cultures, for example in early medieval European societies as well. This feature is the absence or at least the underdevelopment of the concept of justice as 'intangible' and invisible, that is an abstract value with absolutely positive importance which any law should ensure on daily bases. On the contrary, an archaic law, such as the law of Nahuas (as it belongs to this category as well), is based on actions which should enforce concrete or so to speak 'visible' or 'tangible' justice. An archaic law is pragmatic, it resolves practical problems of everyday life, even if often by means of rituals, since the sacral and profane spheres of people's life are intertwined and the results of rituals are viewed by them as something real. Thus, the Nahua adulterers were not punished because it was fair but because it was necessary to perform the ritual (the stoning) which "repaired" or "restored" the world order disturbed by the adultery.

\section{Conclusion}

For the Nahuas, the social order was a part of the supernatural world order and thus the remedy for the damage caused by a delict should be supernatural as well. The means of this

12 On archaic legal thinking see e. g.: HATTENHAUER 1998:1 ff.

DOI: 10.1515/eas-2017-0008 @ University of SS. Cyril and Methodius in Trnava. All rights reserved. 
remedy - specifically the punishment of a delinquent - was a ritual with a certain religioussymbolic content, which was particularly true of the execution of the death penalty, which was imposed for committing many crimes considered to be serious.

Criminal law became the most effective instrument of social control in Tenochtitlan and Texcoco. It was based on solid ideological foundations that gave some more importance to the prosecution and punishment of criminals - the repression of the perpetrators was the means to maintain the proper "course" of the supernatural order of the world. Since the maintenance of it was understood in Tenochtitlan, Texcoco, and elsewhere in Mesoamerica, as the main function of the state, it is not surprising that a monopoly of the state emerged in the prosecution and punishment of offenders, and that there was also public interest in this prosecution and punishment.

Although the result of the information outlined above about Nahua understanding of delinquency is that the association of the Nahua society with the so-called shame cultures is justified, I believe that at least that part of the Nahua society, the people who lived in Tenochtitlan and Texcoco, have, over time, changed to a certain extent to a guilt culture.

For shame cultures, it is typical that the delinquent's shame extends to people a delinquent is associated with somehow, for example by family relationships, while these people bear the penalty imposed on the offender together with him. In Tenochtitlan and Texcoco, however, with but one exception, only the persons who committed a crime, and not their relatives, were punished. The exception is the crime of treason, in case of which, besides the traitor (by death penalty), his family was also punished (by enslavement).

On the other hand, the Nahuas might have been thinking that the shame of a concrete delinquent spread from him to the whole society, since all people were responsible for the proper functioning of the supernatural world order and should "repair" it if it was necessary. A means to do so was, inter alia, the ritual punishment of offenders who disrupted the order. It is no surprise that a public interest existed to prosecute a punishment of delinquents in Tenochtitlan and Texcoco.

Thus, the crime of an individual perpetrator cast shame not only on him but also on the society as a whole (despite its considerable social differences and legal inequality, all inhabitants of Tenochtitlan and Texcoco were joined since all were called to participate in the fulfilment of the supernatural mission mentioned above and formed a single community for this most important purpose for them). From a practical point of view, however, the whole society, even if ashamed, could not be punished, especially if the punishment that was often imposed was a death penalty. Therefore the members of the society "shifted" 
their shame to the perpetrator, noticing him as a shameful person, but de facto also as someone who is individually guilty of committing a crime, so that to eliminate the society's shame was enough to punish a society's individual member - the perpetrator. The immediate reason for punishing the perpetrator was not his shame but guilt.

I further believe that the image of Tenochtitlan and Texcoco as shame culture also disturbs the progressive development of complex phenomena typical of guilt cultures in these citystates. These phenomena include introduction of vertical, i.e. the state-controlled socialcontrol system - shame as a means of social control is applied in the framework of horizontal human relations - and the establishment of a state organization and, in particular, of the state bodies making up and applying the law, as well as the legal order comprised of binding and by state and divinely sanctioned expressing norms. As a consequence of these phenomena, the social-control function of shame was considerably weakened, as the state power and the law enforced by it became the main instrument of social control, and in committing the delict it was not so important that the offender fell into disgrace, but that he became responsible for violation of a legal norm expressing the will of the state and the gods, and this responsibility was conceptualized as guilt (ASSMANN 2012:166). As these phenomena appeared in Tenochtitlan and Texcoco during the 15th century, the hypothesis of a gradual change in the character of the pre-Hispanic Nahua society from the shame culture to the guilt culture may have some justification.

\section{Bibliography}

ALBA, C. H. (1949): Estudio comparado entre el derecho azteca y el derecho positivo mexicano. México: Instituto Indigenista Interamericano.

ALMAZÁN, M. A. (1999): The Aztec States-Society: Roots of Civil Society and Social Capital. In. Annals of the American Academy of Political and Social Science, 565 (1), pp. 162-175.

ALVA IXTLILXOCHITL, F. de (1997): Obras Históricas, I. México: UNAM.

ASSMANN, J. (2012): Panství a spása. Politická theologie ve starověkém Egyptě, Izraeli a Evropě. Praha: OIKOYMENH.

BENEDICT, R. (1947): The Chrysanthemum and the Sword. Patterns of Japanese Culture. London. Secker \& Warburg. 
BERDAN, F. F. (2014): Aztec Archaeology and Ethnohistory. New York: Cambridge University Press.

CREIGHTON, M. R. (1990): Revisiting Shame and Guilt Cultures: A Forty-Year Pilgrimage. In. Ethos, 18 (3), pp. 279-307.

DURÁN, D. (2002): Historia de las Indias de Nueva España e Islas de Tierra Firme, II. México: Consejo nacional para la cultura y las artes.

Fikentscher, W. (2009): Law and Anthropology. Outlines, Issues, and Suggestions. München: Verlag der Bayerischen Akademie der Wissenschaften.

GEERTZ, C. (1973): The interpretation of cultures: selected essays. New York: Basic Books.

HAMANN, B. (2002): The Social Life of Pre-Sunrise Things. Indigenous Mesoamerican Archaeology. In. Current Anthropology, 43 (3), pp. 351-382.

HATTENHAUER, H. (1998): Evropské dějiny práva. Praha: C. H. Beck.

HILL BOONE, E. (2000): Stories in Red and Black. Pictorial Histories of the Aztecs and Mixtecs. Austin: University of Texas Press.

HODGE, M. G. (1996): Political Organization of Central Provinces. In. Berdan, F. F. et al. (eds.): Aztec Imperial Strategies. Washington, D. C.: Dumbarton Oaks Research Library and Collection, pp. 47-88.

INOMATA, T. (2006): Plazas, Performers, and Spectators. Political Theaters of the Classic Maya. In. Current Anthropology, 47 (5), pp. 805-842.

JANDOUREK, J. (2012): Slovník sociologických pojmů. 610 hesel. Praha: Grada Publishing.

JOHANSSON K., P. (2010): Miquiztlatzontequiliztli. La muerte como punición o redención de una falta. In. Estudios de Cultura Náhuatl, 41, pp. 91-136.

JOHANSSON KERAUDREN, P. (2009): La literatura indigenista en la Nueva España en los albores del siglo XVII. In. Masera, M. - Flores, E. (eds.): Ensayos sobre literaturas y culturas de la Nueva España. México: Universidad Nacional Autónoma de México, Instituto de Investigaciones Filológicas, pp. 33-72.

KATZ, F. (1989): Staré americké civilizace. Praha: Odeon.

KOHLER, J. (2002): El derecho de los aztecas. Published together in one volume with: CERVANTES Y ANAYA, J. de: Introducción a la Historia del Pensamiento Jurídico en México. México: Tribunal Superior de Justicia del Distrito Federal. 
KOVÁČ, M. (2002): SInko jaguára. Náboženský svet Olmékov, Mayov a Aztékov. Bratislava: Chronos.

LEÓN-PORTILLA, M. - SILVA GALEANA, L. (1991): Huehuetlahtolli. Testimonios de la antigua palabra. México: Fondo de Cultura Económica.

LEÓN-PORTILLA, M. (1993): La Filosofía Náhuatl estudiada en sus fuentes. México: UNAM.

TORQUEMADA, J. de (1969): Monarquía Indiana. Tomo segundo. México: Editorial Porrúa.

LÓPEZ AUSTIN, A. (1961): La Constitución Real de México Tenochtitlan. México: UNAM.

LÓPEZ AUSTIN, A. (1985a): La educación de los antiguos nahuas 1. México: Secretaría de Educación Pública.

LÓPEZ AUSTIN, A. (1985b): La educación de los antiguos nahuas 2. México: Secretaría de Educación Pública.

LÓPEZ LUJÁN, L. (1989): La recuperación mexica del pasado teotihuacano. México: Instituto Nacional de Antropología e Historia.

LÓPEZ LUJÁN, L. - LÓPEZ AUSTIN, A.: Los mexicas en Tula y Tula en MéxicoTenochtitlan. In. Estudios de Cultura Náhuatl, n³8, 2007, pp. 34-83.

LUZ LIMA, M. de la (1986): Control Social en México Tenochtitlan. In. Criminalia, LII. Nos. 1 - 2. Ene - Dic., pp. 7-28.

LOCKHART, J. (1992): The Nahuas after the Conquest: A Social and Cultural History of the Indians of Central Mexico, Sixteenth through Eighteens Centuries. Stanford, CA: Stanford University Press.

LÜDTKE, A.: Chapter I: Introduction: What Is the History of Everyday Life and Who Are Its Practitioners? In. Lüdtke, A. (ed.): The History of Everyday Life. Reconstructing Historical Experiences and Ways of Life. Princeton, New Jersey: Princeton University Press, pp. 3-40.

MILLER, G. P. (2005): The Legal Function of Ritual. In. Chicago-Kent Law Review, 80 (3), 2005, pp. 1181-1233.

NAVARRETE LINARES, F. (1997): Medio siglo de explorar el universo de las fuentes nahuas: Entre la historia, la literatura y el nacionalismo. In. Estudios de Cultura Náhuatl, 27, pp. 155-179.

OffNeR, J. A. (1983): Law and Politics in Aztec Texcoco. Cambridge: Cambridge University Press.

DOI: 10.1515/eas-2017-0008 @ University of SS. Cyril and Methodius in Trnava. All rights reserved. 
SAHAGÚN, Fray B. de (2001a): Historia general de las cosas de la Nueva España, I. Madrid: Dastin.

SAHAGÚN, Fray B. de (2001b): Historia general de la cosas de la Nueva España, II. Madrid: Dastin.

SMITH, M. E. (2000): Aztec City-States. In. Hansen, M. H. (ed.): A Comparative Study of Thirty City-State Cultures. Copenhagen: Royal Danish Society of Sciences and Letters, pp. 581-595.

SMITH, M. E. (2005): City Size in Late Postclassic Mesoamerica. In. Journal of Urban History, 31 (4), pp. 403-434.

SMITH, M. E. (2008): Aztec City-States Capitals. Gainesville: University Press of Florida.

SMITH, M. E. (2012): The Aztecs. $3^{\text {rd }}$ ed. Hoboken, NJ: Wiley - Blackwell.

THOUVENOT, M. (2014): Diccionario náhuatl-español basado en los diccionarios de Alonso de Molina con el náhuatl normalizado y el español modernizado. México: UNAM, Instituto de Investigaciones Históricas.

TORQUEMADA, J. de (1969): Monarquía Indiana. Tomo segundo. México: Editorial Porrúa.

TURNER, V. (1991): The Ritual Process. Structure and Anti-Structure. Ithaca, New York: Cornell Paperbacks.

VYŠNÝ, P. (2012a): Štát a právo Aztékov. Trnava: Typi Universitatis Tyrnaviensis.

VYŠNÝ, P. (2012b): Funkcia tlatoaniho $v$ aztéckom Tenochtitlane. Ethnologia Actualis Slovaca, 1, pp. 71-110.

VYŠNÝ, P. (2015): Grundprobleme der Erforschung des aztekischen Rechts. Societas et lurisprudentia, year III, no. 3, pp. 71-103.

YING WONG - TSAI, J. (2007): Cultural Models of Shame and Guilt. In. Tracy, J. L. Robins, TRACY, J. L. - ROBINS R. W. - TANGNEY J. P. (eds.): The Self-Conscious Emotions, Theory nad Research. New York, London: The Guilford Press, pp. 209-224. 